\title{
From Populism to Democratic Polity: Problems and Challenges in Surakarta, Indonesia
}

\section{Pratikno and Cornelis Lay}

\begin{abstract}
The paper discusses democratisation practiced in Surakarta, Indonesia, which has been claimed by many experts as a municipality with "best practices" of democratic local governance in Indonesia. Their analyses focus on the actors and claim that participation is a possible way of crafting stable democracy. This participation in turn, they suggest, is a result of decentralisation which thus strengthen local democracy. Presenting the civil society participation and the decentralisation in the city of Surakarta, this paper shows that what actually happens is otherwise. It argues that the rise of popular participation was rooted in contentious local politics. Besides, the constitution of the new forms of popular representation are not supported by, and produced within, a clear ideological framework from the people in Surakarta.
\end{abstract}

\section{Introduction}

Participation through civil society and decentralisation has become the main theme within the current debates about democratisation. ${ }^{1}$ The assumption is that participation and decentralisation will strengthen democracy. The best Indonesian case in favour of these theses must be Surakarta municipality,

1 We would like to thank Lukman-nul Hakim for his valuable contribution in both the discussion and editing, and HendraTry Ardiantoand BelaNagariin providing data. 
34 also known as the city of Solo. Solo has become well known in the Indonesian debate because of its recent positive experience of popular participation. They include efforts at participatory budgeting and planning, in cooperation between political executives, various CSOs and social movements. Many development agencies and pundits refer to Surakarta's experiencesin terms of "best practices" of democratic local governance in Indonesia. Theiranalyses focus on the actors andclaim that participation is a possible way of crafting stable democracy. This participation in turn, they suggest,is a result of decentralisation which thus strengthens local democracy.

But on a closer examination, dothe developments in Solo really support the optimistic theses? Fourseparated critical argumentsthat are generally overlapping suggest otherwise. One argument points to weaknesses in the participatory approach. Another claims that decentralisation has mainly come with elite-capture. Yet another emphasises the problems of popular representation. Thefourth acknowledges that while local strongmenmay need to go beyond clientelism to win elections, which may open up for popular participation, butthere are many inbuilt contradictions. Before we proceed by discussing the case of Solo, let us present these critical perspectivesin somewhat more detail.

\section{Participation-Democracy Nexus: A Missing Link}

Within the debate on decentralisation and development in bringing about local democratic governance, participation has been widely advocated as a main way to compel government to be more responsive and transparent (Aspinall \& Fealy, 2003, pp.4-8). It is worthy noticing that decentralisation phenomena across the world are impossibly separated with the changing orientations of global development agencies (Hadiz, 2010)(Hadiz 2010; Harris et al., 2004). Dominant perspectives, mainly propagated by the World Bank, have changed global development trajectories from reducing state's roles into enabling state capacities and improving its legitimacy through encouraging greater public participation in decentralised governance. 
In order to craft democracy, the World Bank emphasises people participation as a fundamental requirement. The Bank conceives participation as aggregated interests which are seen as being articulated by and through NGOs and local associations. Furthermore, it is also perceived that differences between various groups of societies in articulating their interests rest with 'differing endowments of social capital, informal rules, norms and long-term relationships that facilitate coordinated action' (World Bank 1997: 114). Inspired mainly by Robert Putnam (1993), the Bank subsequently defines social capital as "the norms and social relations embedded in the social structures of societies that enable people to coordinate action to achieve desired goals" (cited via Harriss 2002: 84).

The concepts of participation, civil society, and social capital in the current development and decentralisation discourse have become highly blurred and overlapping. As Ben Fine (2001) reminds us, the World Bank's version of social capital appears to conceptually undermine the importance of social conflict and the dynamics of unequal power relations in determining development trajectories. In this version, concepts of participation and civil society-which rather constitutes an arena of struggle between competing intereststhus become theoretically sterilised and apolitical (Hadiz 2010: 31). Social capital in its present manifestations, therefore, has become a fundamental element of the wider technocratic project to depoliticise development and democracy. Social capital is merely, to quote John Harriss "a weapon in the armoury of the anti-politics machine" as it is not a civic notion to politically empower society but to make them technocratically manageable (Harriss 2002: 13; Harriss etal 2004; Ferguson 1994). This idea, therefore, holds out the prospect of the introduction to certain institutions that may foster democracywithout permitting political competition or conflict between different social groups and classes, and it turnsmany institutions into formalities.

\section{Elitist decentralisation}

Decentralisation is also not a panacea. After a decade of comprehensive and radical decentralisation in Indonesia, there are still severe problems in participation and democracy. The paradoxes 
36 of participation-democracy relations between neo-liberal and prodemocracy versions in decentralised governance are well represented. The implementation of decentralisation framework in 1999, after the 32 years of centralistic and authoritarian Suharto regime, was widely welcomed by both "neoliberal technocrats" and prodemocratic movements as an essential way to build democracy. There were common expectations and beliefs at that time, introducing such institutional frameworks would bring about local democratic and effective governance. Contemporary studies on Indonesian local politics, however, are characterised by general conviction that applying democratic institutions do not automatically bring about democratic polity (e.g. Nordholt and van Klinken 2007). There is an increasingly common call instead for theclose examination of power relations in participation and democracy for the specific context.

Robison and Hadiz'sReorganising Power in Indonesia (2004), for instance, convincingly demonstrates that democratic institutions in the post-Suharto era are hijacked by the old oligarchic business and political power which are able to successfully accommodate themselves in the new system. The paradox of democracy and democratisation, according to Robison and Hadiz, is not stemming from institutional formats but from the complexities of social conflict which old business and political elites involve in preserving their interests and power. They paradigmatically challenge actors based approach in democratisation studies, as prominently propagated by transitologist and good governance perspectives, which highly emphasis on institutional changes through elite pact and technocratic crafting. They also argue that such approach has severely neglected analysis on techniques, procedures, and power relations mechanisms in political economic institutions in which power actually operates.

Nordholt's Decentralisation in Indonesia: Less State, More Democracy? (2004) investigates the current relations of politics and democracy in Indonesia through post-colonial lenses. He argues that the current local political elites are products of prolonged power configuration between bureaucracy and local aristocrats since colonial period (politics of indirect rule). These local aristocrats were soon absorbed into local and national bureaucracy after the 
Indonesian Independence. The implementation of decentralisation has, again, significantly increased local aristocrats' roles in the local levels. Through the term 'changing continuities', Nordholt asserts that decentralisation and democratisation have not significantly transformed the old patrimonial characters of Indonesian politics (see also Nordholt and van Klinken 2007; Dwipayana 2004).

Furthermore, wide democracy assessments 'from below' conducted by the research oriented NGO Demos in cooperation with the University of Oslo (Piryono, et al. 2007 and Samadhi and Warouw 2009) succinctly conclude that democratisation in this country is actually facing a crisis; that democratic institutions have been taken over by elites for their own interests.

\section{Problems of popular representation}

Why has this occurred? In comparative perspective, the contributors to Harris et al.(2004) and Törnquist, et al. (2010) have concluded that the prominent problem of new local politics is that the development of democracy has been depoliticised. The core problem of this 'democratic deficit', according to Törnquist and others, is not that there are imperfections with regard to

...the new and positive civil and political freedoms, but rather that the defunct instruments and popular capacities to exercise control over public matters have made it difficult to use the freedoms and new institutions to alter the relations of power and thus improve law, policies and governance (Törnquist, etal. 2010: 5).

In order to deal with current problems of democracy, this argument suggests that the influence of popularity to alter the structure of power and to open up for political transformation is most essential. It inevitably calls for the analysis on politics of representation. It is in this new conceptual framework that the actual relations between participation and democracy can be problematised in a more fruitful way. The ultimate task for improved democratisation is, therefore, to bring the political dimension back into the participation-democracy nexus.

Within a similar context, Avritzer's account on contemporary democratisation in Latin American countries is highly important to 
38 be addressed. In Democracy and Public Space in Latin America (2002), he notes, in the same vein as Harriss et al. (2004) and Törnquist et al. (2009), that transition theory of democratisation-that has been particularly well developed in regard to Latin America through the works of Guillermo O'Donnell and Philippe Schmitter,for instance-has over-emphasised on the roles of political elites and thus neglected the significance of recent popular political movements. Transition theories recognise the possibility of undemocratic and pro-democratic mobilisation and collective action, but limit the role of mobilised masses to the negotiation with elites.

Through illustrative case studies on Brazil, Argentina and Mexico, Avritzer demonstrates that democratic collective action within these respective countries has opened a space for political participation and challenged 'traditional (hierarchical and clientelist) understanding of politics' (2002: 3), and that there are institutional designs — as in the case of participatory budgeting — whereby such democratic participation may be linked into political system. By 'participatory publics' concept, he normatively noticed that:

... democratization is the result of transformation at the public level and that full democratization is the capacity to transform new practices from a societal innovation into a public form of decision making (Avritzer, 2002, p.5)

Avritzer's main contribution is that he has opened up the possibilities to understand democratisation beyond competition between elites. He also emphasises on the importance of political linkage between the emergence of democratic institutions in which citizens can equally participate in determining development orientations (Avritzer 2002: 35). It is true that Avritzer's idea about participatory publics is highly normative. The prospect for this participatory model for building democracy, therefore, should be assessed through cautious analysis of the politics of local sphere.

\section{Post clientelism}

Politics towards the kind of practices of fostering popular representationvisualised by Avritzer have been most promising in 
the framework of participatory planning and budgeting in Brazil (e.g. Baiocchi 2003 and Baiocchi and Braathen this volume) and the Indian state of Kerala (e.g. Tharakan 2004). Meanwhile appreciative scholars like James Manor (2010 and this volume), however, argue that such achievements call for extensive political facilitation; in Brazil by the new Labour Party (PT) and in Kerala by a popular education movement in combination with leading segments of a Left Front Government. The problem, according to Manor, is that such political support is quite unrealistic in most parts of the global South.

Instead, Manor points to a less ideal yet existing possibility for civic action to make a difference in context that leading politicians and parties no longer can win elections only by means of patronage politics. In the context of what he therefore labels 'post-clientelism', politicians also have to attract voters from wider sections of the population, including by populist measures. Hence,some politicians opt for cooperation with well reputed leaders and organisations in civil society too; to gain additional votes from enlightened middle classes and the vulnerable people that are supported by the CSOs. The dynamics of post clientelism is quite volatile, Manor adds. But, is this a better way of understanding the developments in Solo?It anywayremains to be analysed: what problems and options for local democracy that could develop under such conditions?

\section{The enquiry}

What perspective is most fruitful, then, in understanding the developments in Solo? Two processes seem to be critical to examine irrespective of perspective. Firstly, it's about the dynamics of linkagesbetweenpolitical commitment of local government to people participationon the one handand the civic engagement on the other hand. Secondly, the extent to which the thus generated participation in local governance can transform, potentially, the existing fledgling democratic institutions - and thus effectively bring about a further developed democratic polity in Surakarta?

The next major sectioninvestigates, thus, the making of public participation in Surakarta. One result, which tends to be neglected 
40 by all the previously cited arguments, is the importance of the historical roots of popular mobilisation in the area. In the third main section we present therefore also a prolonged history of the organised civic engagement that has constituted Surakarta as one of the main sites of resistance in Indonesia since $18^{\text {th }}$ century. Finally, against this backdrop, we shall provide a critical analysis on problems and potentials for transforming Surakarta's current politics to build democratic polity.

\section{Politicising Representation: A Blessing in Disguise?}

The general Indonesian elections in 1999, with 48 political party contestants, has apparently changed political configuration and thus become a turning point for current political structure in Surakarta municipality. It was the first democratic election that was held soon after the resignation of President Suharto in May 1998. During the Suharto periods, as in many other areas in Indonesia, political configuration of parliament and executive bodies in Surakarta was continuously dominated by military figures and those from Golkar-the government party. The Indonesian Democratic Party for Struggle (PDIP) led by Megawati-a daughter of the first Indonesian President, Sukarno, and a symbol of resistance during the authoritarian rule-got landslide victory in the election with 56,7\% votes and also won in all sub-district levels in Surakarta municipality. The PDIP effectively controlled 24 out of 45 numbers of seats in the local parliament (53\%). There were almost no significant competitors for the PDIP in the parliament as other parties got only small number of seats. Even the Suharto's old Golkar Party and the Muslim based United Development Party (PPP), which were previously dominant in Surakarta, only gained two and one seat respectively (Lay 2000: 99-103). ${ }^{2}$

2 Political configuration in Surakarta after the 1999 general election is presented as the following. The Indonesian Democratic Party for Struggle (PDIP) gained landslide victory with $56.7 \%$ votes and 23 numbers of seats in the parliament. The second winner went to National Mandate Party (PAN), an IslamistNationalist party, with $13.89 \%$ votes and 6 seats in the parliament. The old government party-Golkar and Muslim-based party, PPP (United Development Party), which were previously dominant in Surakarta, only gained 13,89\% (2 seats) and $3.99 \%$ (1 seats) respectively. More interestingly, the Indonesian 
However, rivalries among PDIP cadres came about when the local parliament elected the mayor and its deputy after the 1999 election. At that time, the head of local governments in Indonesia were still elected by the representatives of the local parliament, whereas direct election for head of local governments were subsequently implemented in 2004 after the amendment of the Local Government Act No. 22/1999. ${ }^{3}$ Although the mayor candidate, SlametSuryanto, had huge support from ordinary people and PDIP cadres in Surakarta, his support in the parliament was extremely low. He was only supported by 9 out of 23 (23\%) PDIP delegates in the local parliament (Lay 2000: 103). The major votes of the PDIP went to Suryanto's rival, Suhendro.

Disappointed by his own party and most of its representatives in the local parliament, Suryanto's group then built new political support by approaching J. Soeprapto of the then fraction of five members in local parliament which represented the military and police. Thus, SlametSuryanto-J.Soeprapto were subsequently elected as mayor and deputy of Surakarta municipality without political support from Suryanto's original party, the PDIP.

It paved the way for continuous conflicts between the political executive and legislative bodies in Surakarta. SlametSuryanto is a typical example of the kind of leader which in Indonesia used to be labelled solidarity maker, that is, he is very good at mobilising popular support, often by way of populist views and measures. On the other hand he had no adequate experience in administration and in governing public institutions. He, thus, relies heavily on the municipal secretary and on bureaucrats in conducting his duties. As a consequence, the conflicts are not merely between the parliament and Suryanto itself, but also between the parliament and Surakarta's bureaucracy. Furthermore, the conflicts were not only through dayto-day controversial statements over certain issues, but also in formal

Christian Party (KRISNA) got $1.07 \%$ votes, but had no representative in the parliament (Lay 2010).

3 The direct local election was mandated by the Local Government Act Num. 32/2004 which replaced the previous decentralisation act. There are several major changes in this new framework, including the implementation of direct local election for head of both district and provincial governments. 
42 political processes. Many government initiatives were gaining less support - and even resistance-in the parliament. It culminated when all political party fractions in the parliament rejected the mayor's Accountability Report in April 2001. ${ }^{4}$

In order to challenge the political pressures from the parliament, the local government, then, turned to encourage public participation. The Local Development Planning Body (Bappeda) is unit in local government administration that was often pressured by the parliament due to its main role in local development planning. Technocratic arguments of Bappeda, even if very good, often failed to gain political legitimacy by way of support from the members of the local parliament. The parliament members consider that they are more legitimate as they represent people through electoral representation, while the bureaucracy does not. From the point of view of those who appreciated the proposals from within the administration and wanted to relate to them, it called for new kind of people representation that could challenge the legitimacy of the parliament. Therefore, participatoryplanning and budgeting advocated by the Bappedabecome an essential way for social movement and civil society activists and their partners within politics of politicising and expanding popular representation.

Outside public governance and as part of massive NGO programs on strengthening civil society in the post-Suharto era, civic engagement in Surakarta was also widely organised (Rivai et al., 2009). By contrast to most other cities and districts, there were effective intergroups forums in Surakarta, namely the Study Forum for Democracy and Social Justice (Forum StudiDemokrasidanKeadilanSosial, FSDKS) and a NGO Forum facilitated by the Institute for Rural Technology

4 Due to this rejection, the mayor had to revise and read the second report before the parliament. In order to pave the way for the second chance, the mayor had to "accommodate" parliament interests. For instance, he gave the concession to increase the local budget for parliament members' wage. Furthermore, the mayor had to discipline his government officials who are complained by the political fractions as being suspected for corruption in several projects. The mayor's efforts were successful and the second Accountability Report that he read before the parliament's plenary meeting in 23 May 2001 was subsequently accepted through voting with 28 votes. See Radar Solo, 6 April 2001 and Radar Solo, 24 Mei 2002. 
Development (LembagaPengembanganTeknologiPedesaan, LPTP).

These forums became embryos for further participatory initiatives in decentralisation era. In January 2001, they set up a joint actionsocalledSynergy Forumwhich involved more stakeholders, including NGOs, academics, bureaucrats, local association, to address local autonomy issues (Pratikno 2005). This Forum had facilitated the birth of Local Regulation on the Institute for Villages' Community Empowerment (Lembaga Pemberdayaan Masyarakat Kelurahan, LPMK), a regulatory framework for participatory planning and budgeting in village levels in Surakarta municipality.

Some external interventions are also worth noticing with regard to the strengthening of participatory planning initiatives. In the 2000s, the Ford Foundation supported three NGOs, namely Gita Pertiwi, Leskap, and Inres, to establish the Consortium for Monitoring Public Institution Empowerment (Konsorsium Monitoring dan Pemberdayaan Institusi Publik, KOMPIP), the aims of which were to develop and map local governance issues. It was a multi-stakeholders consortium that involved Bappeda, and representatives from the Solo university and NGOs. ${ }^{5}$ The Ford Foundation enabled the Consortium to make a comparative study on the government and society relations in local budgeting in the Philippines in the early 2000s. Such partnership was subsequently institutionalised through the establishment of IPGI Solo (Indonesian Partnership on Local Governance Initiative). IPG Solo was thereby part of a wider network including IPGI Bandung in West Java Province and IPGI Dumai in Riau province. IPGI's main focus was to develop participatory planning mechanisms that were tested out in 2001 (Rivai et al. 2009: 37).

Another important intervention was the Breakthrough Urban Initiative Local Development (BUILD) Program, initiated by the UNDP and the Ministry of Home Affairs (Departemen Dalam Negeri, Depdagri) in the 2000s. The program mainly focused on improving public services and participation. It was through the BUILD Program that village-based facilitators benefited various

5 This program involves Drs. Qomaruddin, MM (head of Surakarta's Bappeda), Drs. Totok Sudarsito (Dean of Social and Political Faculty, State University of Solo), and Agus Dodi Sugiarto of Gita Pertiwi. 
44 training on participatory budgeting (Histiralludin 2004). At that time, participatory budgeting was still conducted in spatial or territorial basis wherein villages became its main working units.

In addition, as a part of the BUILD Project, UNDP subsequently introduced the City Development Strategy (CDS) program with the aim of strengthening the involvement of especially vulnerable groups in urban sectors targeted for reforming participatory planning and budgeting, which otherwise was based on territorial communities. These so-called sectoral groups thus included urban street vendors, rickshaw driver, traditional market, hawkers, buskers as well as sex workers. Interestingly, this initiative was welcomed and supported by the local government through Mayor Suryanto' Decree No.410/45A/I/2002 on Involving Sectoral Groups issued in 2002. In practice, the participation of sectoral groups was mainly facilitated by the Working Team of City Development Strategy which then focused on three issues: social conflict, urban management, and marginalised society (Rivai et al., 2009: 37-40).

The local government subsequently tried to encourage sectoral groups' participation in the existing territorial-based development planning that hierarchically started from Muskelbang (villages-level development forum), Muscambang (sub-district-level forum) and Muskotbang (Municipal-level forum) through theMayor Decree No.8/2003. It provedsimply impossible, however, to accommodate the rapidly expanding sectoral groups with their interests and demands in the territorial based development forum, particularly on the village level.

The most significant achievement was instead that the local government issued the Mayor Decree No.3/2004 on Technical Guidance for Participatory Development Planning that encouraged sectoral groups to hold Focus Group Discussions (FGD) in their own respective communities or groups. The FGD's results, according to this Decree, would be possible to synchronise with related municipal departments without being channelled through territorial-based participatory planning forum. In other words, local government applied two models of participatory planning - territorial and sectoral 
basis.

Numerous sectoral groups' FGDs were effectively facilitated by local NGOs under the coordination of the Bappeda. This model has massively increased participation level in Solo city of vulnerable people in sectors and areas subject to 'urban development' and reform. The Bappeda thenfollows up the FGDs results by organising Limited Group Discussions (Diskusi KelompokTerbatas, DKT) to synchronise various demands. ${ }^{6}$ The DKT results become prominent input for related municipal departments in designing development programs. This sectoral based participatory planning was then integrated into the existing development planning forum in the municipality level.

It is obvious that political conflict between the executive government and the parliament forced Surakarta municipality government to seek wider support from society. In other words, political momentum for initiating participatory planning and budgeting in Surakarta is unable to be separated from the context of this antagonism. The commitment of local government to involve popular participation underwent in the advantageous situation for many local and international NGOs which actively supported various programs on public participation.

Unlike the Kerala's experience wherein Peoples' Planning Campaign (Tharakan 2004: 108-109) is the results of the prolonged ideological struggle and gets the momentum-when the Left and Democratic Front (LDF) won the 1996 local election and was gaining power-the Surakarta's popular participation is thusshort of ideological foundation and is less based on extensive popular organisations and also less institutionalised.

\section{Historical Roots of Popular Mobilisation}

Besides the political setting that forced government to involve people involvement in policy making, Surakarta has a long history of

6 Many local NGOs actively facilitate sectoral groups' FGDs as the following: small retailers groups are facilitated by Leskap, children workers are facilitated by Sari,pedi-cab drivers by SekolahWarga Mandiri, singing beggars are mediated by Inres, women groups by Spekham, while diffable communities are facilitated by Interaksi, Lampu and Talenta (see Rivai etal. 2009: 41). 
46 its organised popular mobilisation. Even if it has been undermined during Suharto's authoritarian rule, it is still present in people's minds and thus worthy of taking into account.

As early as $18^{\text {th }}$ century, Javanese kingdoms were characterised by endless elite conflicts resulted in their collapse and division into smaller kingdoms. Since the VOC (Vereenigde Oostindische Compagnie, the Dutch company in East India) period in $17^{\text {th }}$ century, the Dutch often exploited such internal conflicts for their own interest through devide et impera policies.

In 1743, King Pakubuwana II in Kartasura (immediately north-west of Solo) was supported by the Dutch to reign power after facing prolonged rebellious movements. The King soon moved the kingdom's capital to Solo and immediately changed the name into Surakarta - a reversed version of the old kingdom's capital. The King had to grant the whole Javanese coastal areas for VOC interests as a concession. Within this setting, the Kasunanan Kingdom of Surakarta was established and was also marked by the first infiltration of the Dutch colonial in the heart of Javanese power. Soon after the establishment of Kasunanan Kingdom, a contending kingdom was built in Yogyakarta through the Giyanti Peace Agreement in 1755 and HamengkuBuwono I became the first King. Only two years later, another rival - the Mangkunegaran Kingdom-was set up in the Solo area after deadly rebellious movement led by Mas Said (Siraishi 1997: 1-3; Pemberton 2003: 55).

The initial popular mobilisation in Surakarta, beyond the elite struggles, was massively organised against the Dutch imposed cultivation of cash crops, the Cultuurstelsel (Tanam Paksa), proposed by J. van den Bosch. This forced cultivation system was introduced to recover the Dutch' economic bankruptcy after the Javanese War (1825-1830). This new system called for a new approach to governance. The Duth had to collaborate with local aristocrats who controlled lands for developing plantations. In this period, colonisation was conducted through indirect rule and local monarchy was still effectively governing their people. It was through this system that concepts of labour divisions, argiculture commercialisation, 
and contracts system were subsequently introduced in Java. In the Javanese feudal system, local aristocrats occupied the whole lands and gave their rights for managing and processing their lands to bekel (superior tenants). It was through bekel that common people were working in farms and plantations with unfair earnings (Suhartono 1991). The Cultuurstelsel system was thus effectively applied within the feudal system ruled by local leaders and kingdoms with exclusive support from the Dutch colonial.

The Cultuurstelsel system made Surakarta's people more marginalised and living in acute poverty as they often had to leave off their farms for working obligation in the Dutch's plantations. This situation brought about peasant protests. Shiraisi (1997: 2325) identifies two types of people's resistance in Surakarta. First, it is aboutthe individual and sporadic actions against plantation controllers for protecting people's lands and personal revenge. In this periods, namely 1860-1870s, there were many kecu (thug) whom were hired to kill and torture European people in the plantations. In addition, people were also frequently burning plantation areas as a resistance to the system. Second, popular mobilisation was more organised in advocating their interests. They were often doing nggogol (mass demonstration) by marching to the local leader offices and even to the kingdom. If their protest were failed to be accommodated, they would commit to strike in both kingdom and plantations. The Cultuurstelsel systemhas inevitably brought about popular distrust in local government, thus making the state-society relations quite 'fragile'. Violent conflictswould easily take place whenever the government unable to negotiate with 'its' people.

The development of capitalism coupled with colonial political settings made Surakarta's politics much more dynamic in the early $20^{\text {th }}$ century. Groups of Chinese business built a trading organisation, Kong Sing, aimed at expanding their economic interests in Surakarta and Java. The Islamic Trader Association (SDI)—which then became the influential political organisation Syarikat Islam (SI) that challenged the Dutch colonialism-was initially established to respond the domination of Chinese business in economic realm, particularly in batik (painted clothes) industries (Siraishi 1997: 55-65). 
The birth of SI in 1912 was followed by many modern organisations in Surakarta. Their objectives were not onlylimited to economic interests, but also included political struggle against Dutch colonialism. The most radical were Indische Social-Democratische Vereeniging (ISDV, Social Democrat Association in Dutch India) and the Indonesian Communist Party (PKI), to mention some. These gained massive support in Surakarta. At this period, political organisations were deeply rooted in the sometimes overlapping ideologies of Islam, Nationalism, and Communism and Socialdemocracy in particular. The organisations were competing to gain popular support. In 1918, however, the Leftist movements demonstrated their joint interests and radical characters by challengingthe feudal practices in the two Solo-based kingdoms, Kasunanan and Mangkunegaran. Furthermore, they destroyed plantations and other colonial assets (Larson 1990: 131). These groups had also mobilised labour and peasants to strike. In fact, they made Surakarta city the centre of a general strike in Central Java (Siraishi 1997). The political dynamics of these movements, within a general leftist-nationalist discourse, influenced Indonesian political struggles against colonialism in the 1920-1940s quite significantly.

From 1960, the central government, led by the First President Sukarno, introduced a land reform policy that was essential in attempting to put an end to the feudal model and thus open up opportunity for common people to possess sufficient lands. It is obvious that this land reform policy was closely related to the Leftist ideology as Sukarno himself was also supported by the PKI, which had its main stronghold in the area around Solo and had become the world's third largest communist party. This radical policy with populist president Sukarno in the forefront, however, suffered from conflicts among the poor as well as the resistance of local strongmen and could not be improved and completed ahead of the attempt by dissident officers and a few communist leaders to do away with rightist military leaders came about in 1965 and generated a full scale counter revolution. When General Suharto took over the power, he soon accused the PKI and its sympathisers of having staged a coup and banned PKI and its ideology in Indonesia. The banning of PKI 
was immediately followed by massive killings particularly in Java and Bali, approximately 500.000-2.000.000 victims ${ }^{7}$, and it became one of the worst periods of Indonesian politics.

Suharto immediately put an end to the reforms by removing land reform courts and issuing 'floating mass' policies-efforts to detach people from political activities (Fauzi 1999: 158-159). Suharto's authoritarianism was not only built based on hisrepressive approach, but also included the elimination of any potentially contending ideology. Soon after the banning of PKI and MarxistCommunist ideology, Suharto regime also forced mass organisations to only adopta single ideology, Pancasila. De-ideologisation and depolitisation, therefore, became effective instruments for the regime to discipline people's engagement in political issues.

Surakarta became an important site of resistance, just as in the colonial periods. From 1987 till 1997, for instance, there were many popular protest cases against the government policies and government-supported business projects. For instance, massive protests rejected the establishment of Arum Manis restaurant (1987), Singosaren department store (1988), people demonstration against Sari Warna Asli textile industry (1992) and people rejection on the SDSB, a central government policy to pool 'social' funds through legal gambling. The protests culminated in 1995-1997, just before the 1997 election, when government symbolicallypainted public space facilities with the yellow colour associated with Suharto's Golkar's party as a sign of dominance. It resulted in popular protests by way of re-painting those facilities with the white colour as a symbol of resistance (Budiman and Törnquist 2001). Massive demonstrations were significantly escalated and taken place in various cities which highly contributed to the fall of Suharto regime in 1998. The condition was worsening due to Asian economic crisis that brought about massive riots and violence against groups, mainly Chinese, who

7 There are no precise data regarding the victims of PKI killings in 1965-1966. Robert Crib (1990), based on information from 39 reports and documents, mentioned that the victims range from 78,000 to 2,000,000 people. This destruction makes PKI, the third largest communist party in the world at that time, disappear from Indonesian history. 
50 previously had gained business privileges and thus dominated much of the economy. Besides Jakarta, Surakarta was the most affected and destroyed city.

Clearly, popular mobilisation in Surakarta has thus been quite dynamic throughout history. Such engagement, however, remain limited to resistance against power holders. With the exception of popular movements in the 1900-1960s, there are almost no organised and ideologically-guided movements in Surakarta which contribute to the construction of the contemporary face of popular mobilisation. The banning of communist - and generally the Marxist—influenced ideology and the effective de-ideologisation during Suharto regime have generated much of the fragmentation of the current social movements in Surakarta and Indonesia in general.

\section{Transformative Politics and the Challenge of Democratic Projects}

Decentralisation and democratisation which massively introduced in the post-Suharto era has changed current Surakarta's social and political constellations. As we have already discussed, the strong commitment of Surakarta government to encourage people participation wasconstituted within the context of rivalries between the executive body led by the then Mayor Slamet Suryanto and local parliament. It is worthy noticing that although government affirmation to people participation was instrumental in order for the executives tochallengeelectoral legitimacy of parliament, it opened up a space for negotiation between state and society.

It is only by analysing such antagonisms that one can understand the popular participation in Surakarta's political context. The political rivalries made the local government executives politicising people representation beyond the electoral system. In other words, political antagonism facilitated the constructing of new forms of representation and enables semi-formalised negotiations between local government and Surakarta's people. Dyrbergh (1997) emphasises that:

Antagonism and context mutually constitute and subvert each other: it is the context that conditions and situates antagonism, but antagonism is also constitutive of context in the sense that it shapes, changes and undermines it (194-195). 
Outside the framework of public governance, moreover, as we have demonstrated earlier, people participation in local politics has become much stronger and more organised, partly facilitated by NGOs' programs of strengthening civil society (Suhirman 2009; Handayani 2006a). In addition to the previously mentioned forums which primarily included NGOs, the Solidarity Forum for Peripheral People of Surakarta (Solidaritas Masyarakat Pinggiran Surakarta, SOMPIS), a dialogue forum consisting of various sectoral groups in the city, was established in the 2000s. SOMPIS aims at strengthening marginalisedurban societies' rights and improving their bargaining positions in relation to local government. It is important to mention that the Asian economic crisis in 1997 and 1998, which was particularly devastating in Indonesia, meant that the informal economic sectors increased as people simply had to find ways of surviving, primarily as pedagang kaki lima (small retailers), pengamen (singing beggars), pedi-cab drivers. To make some money theysquatted urban public spaces; and as a result they often faced government's banning and disciplinary actions. The first SOMPIS convention, held in June 2001 and facilitated by KOMPIP Solo (the previously mentioned consortium to monitor the empowerment of public institutions), was attended by more than 56 representatives of 21 sectoral organisations in Surakarta municipality. It is through the SOMPIS that marginalised urban societies in Solo are no longer treated as 'intruders' or policy objects but influential stakeholders in policy making process.

Such considerable changes in the societal level made the linkage between government and people more structured. Within this context, it is important to sketch the political constellations that enabled JokoWidodo and F.X. Hadi Rudyatmoto to take of as mayor and deputy mayors respectively in 2005. It is true that the Indonesian general election in 2004 did not bring significant changes for political constellation in the local parliament of Surakarta. PDIP remained the dominant party in the city. In 2005, however, Surakarta held the first direct local election (pilkada) of the local political executives, soon after the amendment of Local Government Act No.22/1999. In this direct election of mayor and vice mayor, the PDI Phad managed 
52 to close ranks, supported JokoWidodo and F.X Hadi Rudyatmo and won some $35 \%$ votes while their rivals supported by a new postSuharto Muslim party (PAN) got just below 30\% of the votes and as didthe candidates backed by Suharto's old party Golkar and the incoming Indonesian president's Democrat Party. Surprisingly, the incumbent candidates, SlametSuryanto-HengkyNartoSabdo, who believed that they would gain massive support, only got just about $5 \%$ votes. Two important factors contribute to the failure of the incumbent candidates: as F.X. Rudy Hardyatmo became the new leader of PDIP Solo, SlametSuryantohas no longer had control over the most effective political machine in mobilising support that is party structure. It has been aggravated by his involvement in corruption.

Once in office, JokoWidodo and F.X. Rudi Hardyat morealised that they had to somehow strengthen their position, only having been supported by about one third of the electorate. Their solution was to develop populist policies. Widodo is well acknowledged as a visionary person with business background while Hardyatmo is a charismatic figure of PDIP in Surakarta and has wide networks with ordinary people. Soon after elected as mayor, JokoWidodo applied the tourism-sense branding, Solo: The Spirit of Java, that effectively created as sense of 'togetherness' to thus expand their political basis.

Furthermore, and this was the most important strategy, JokoWidodo successfully exploited the government-society linkages that had been structured in the previous period. The paradigmatic case, which are often cited and reported, is the peaceful and successful relocation of almost a thousand retailers of klithikan market (which literally means small but it presumably becomes illegal market as people mostly sell machines component without clear routes of where these goods come from) in the Struggle Monument's city park.

On the surface, many reports and studies put highly emphasis on the personal capacity of the new Mayor Joko Widodo and his Deputy F.X. Hadi Rudyatmo and thus construct them as populist leaders. If we look more detail at this process, however, we willfind that their success is highly determined by the existing Surakarta's political and societal structure. When Joko Widodo sentenced the ultimatum to 
retailers for having to leave off the city parkbefore $17^{\text {th }}$ August 2006, on the Indonesia's Independence day, retailers immediately posed a challenge through their resistance slogan: ngalah, ngalih, ngamuk, ngobong!, a warning of committing massive violence. Thus, there was no other option for the Mayor than torun aseries of negotiations and dialogues. It was certainly not an easy task since the Mayor had to manage negotiation rounds, through dinner meeting and hearings with the public, for approximately 54 times (Suara Merdeka, 14 June 2009). ${ }^{8}$

In the whole negotiation process, the roles played by JokoWidodo in tandem with F.X. Rudy Hardyat mowere highly effective. Hardyatmo, a low-profile yet charismatic figure in PDIP, is widely known by ordinary people and is often conducting direct dialogue, accompanied by the PDIP Satgas. This special task force by the party may not necessarily be described as a gangster or militia group of which there were many in Indonesia at the time (and some are still there). But, when deemed necessary, it was able to command some coercive power. Moreover, Hardyatmo was the head of Banjarsari sub-district, with the retailers in the klitikan city park market. Within the Javanese psyche, such intense and directdialogue is highly effective to persuade people as well as to socialise the government program. People called this as nguwongkewong, or humanising people, strategy. Meanwhile, JokoWidodo with his rhetoric ability constantly constructed the image of Solo as a comfortable and liveable city.

Comparing Solo to othercities and districts in the era of decentralisation, JokoWidodo's populism in terms of strong direct links with the people and standing out as their ultimate representative is unique since he does not build it through pro-people policies related to health and education, which is otherwise most common, but the ability to negotiate with ordinary people thanks to the practices that had already been introduced. Soon after having concluded the negotiation, the

8 This slogan approximately means "If we are defeated and moved away, we will commit to violence and burn (the city)". He had to run negotiation series for seven months with high tension. It was after the $30^{\text {th }}$ meeting, both government and retailers came to begin true dialogue wherein the government could effectively make presentation of their relocation plan. 
54 peaceful relocation of the retailers was celebrated by a huge cultural carnival that gained massive media coverage. This carnival involved the traditional Royal army, artists and local associations, while- and this is the most important - the Mayor and its Deputy were riding horses in the front line to theatrically symbolise their popularity.

Joko Widodo's and Hardyatmo'spopularitywas once more proven by their landslide victory in the 2010 democratic local election wherein they won $90.06 \%$ of the votes. ${ }^{9}$ There are, at least, two explanations forthis. First, JokoWidodo has become a centrum on which plurality of people demands are embodied, particularly due to his ability in managing such difference through constant negotiation and image building of togetherness. Second, the direct election system allows people to individually utilise their rights to vote their candidate. It is essential to be noted that people participation in the 2010 local direct election (Pilkada) in Surakarta municipality was $71.80 \%$, the highest degree of participation in Indonesia (Kompas, 21 Mei 2010).

Various challenges may arise, however, in transforming this populism into more institutionalised democracy. The most critical challenge, as we outlined earlier, is to what extent that the dynamics of negotiation-which is still concentrated around JokoWidodo's populism — can be transformed into certain formula that facilitates institutionalisation of diverse political interests without being channelled through a personal figure. Without transforming such forces into democratic institutionalisation, Surakarta's populism will fall into new forms of bossism or local strongman.

It must be noted, however, that while populism is highly vulnerable by undermining democratic polity, it is alsocrucial in improving democracy. Why? Several leading scholars of politics maintain as of recent that populism is not anevil by definition just because there were populist elements in for instance fascist regimes. Populism may also carry along a potential for building

9 JokoWidodo and F.X. Hadi Rudyatmo were elected as the Mayor and its Deputy of Surakarta municipality for the second term in the 2010 direct local election. They gained landslide victory with $90.6 \%$ votes and won in the whole villages in Surakarta. See Solo Pos, 23 April 2010. 
stable democracy (Laclau 2005; Dyerberg 1997). The foundation of 55 populism, like democracy, is the construction of the people (demos) through collective demands which in turn means the generation of a community that defines what should be meant by popular affairs. Or to quote Ernesto Laclau, it is 'a plurality of demands which, through their equivalential articulation, constitute a broader social subjectivity' (Laclau 2005: 74).Populism only comes about when such various demands are then unified and symbolically embodied in the personal figure. But, it may be democratised.Populism is contingently potential for democratic polity as it, as democracy does, requires politicising popular demands and participation. Without politicising popular demands, as we have argued earlier, the institutions that are supposed to foster democracy are merely an empty shell. Therefore, the challenge of democratic project is to transform this populism, this personal based embodiment of people articulation, into a more institutionalised framework of democratic representation.

\section{Conclusion}

Who is right and who is wrong about Solo? Is it a showcase of how decentralisation and participation can foster more democracy? Or is it flawed by problems of depoliticised and managerial civil society groups, local elitism, lack of representation and the ambiguities of 'post-clientelism? We have argued that the picture is more complicated. Decentralisation provided a framework and donors like the UNDP and Ford Foundation as well as imaginative civil society activists were there. But, so were elitism and poor representation.

In fact, the commitment of local government to initiate participatory planning and budgeting in Surakarta was due primarily to constant confrontation between the political executive (bureaucracy) and parliament soon after the first democratic election in the post-Suharto era in 1999. Unlike the dominant explanations which are highly normative and technocratic, we argue that the rise of popular participation was rooted in contentious local politics. Contending visions of representation forced local government to encourage people engagement to challenge the electoral legitimacy 
of the parliament.

Such conflicts within the elite and such attempts on part of the subordinated classes and groups to use the rivalries to make some advances were nothing new. There has been a long history of popular resistance in Solo since the $18^{\text {th }}$ century. People may not know the technicalities of democracy, but they know what it means and what it takes. Such historical analysis is neglected by most perspectives in the debate. Such analysis reveals active yet fragmentary group of societies which have called for greater accommodation and negotiation both vertically - i.e. between state and society—and horisontally among fragmented groups of societies.

Furthermore, we have also argued that even if the second populist Mayor Joko and his deputy were less haunted by a conflict between the executive and the local parliament as his party PDIP had closed ranks. But they did not enjoy the support of a popular majority, and thus had to further develop his predecessor's populist measures and mobilise the organisational clout of PDIPs not so democratic task force. These measures were in turn supplemented by various development agencies as well as by civil society activists. The Mayor and his deputy Hardyatmo even became favourites of the urban poor. And when their pacts translated into clean streets and less violence, the Mayor in particular turned a favourite of the middle classes, too.

Nevertheless, although there are now comparatively strong links between local government and people through a system of informal though regular negotiations, these rest still with the popularity and the trust in Mayor Joko Widodo and his deputy. Frequent empirical evidences suggest that the attempts at politicising representation in Surakarta's politics remain highly fragile.

On the one hand, the constitution of the new forms of popular representationare not supported by, and produced within, a clear ideological framework. The linkages between government and people are rather, primarily, the result of instrumental politics on part of the dominant actors in the context of political conflict between executive and parliament bodies. It is true that this has at 
times crated openings for social and political activists to develop 57 transformative practices. However, on the other hand, again, the present structures for negotiation between state and people have not yet been institutionalised to survive 'the good populist leader'and thus proceed beyond inconclusive post-clientelism. Such institutions can be created by design in seminars on paper, but they remain an empty shell until the issues and interests that are now being negotiated by a populist leader carried along in more democratic-representative and forceful forms within a strategic ideological and organisational framework. 


\section{Bibliography}

Aspinall, E. \& Fealy, G. (2003) Local Power and Politics in Indonesia: Decentralization and Democratization. Singapore: ISEAS.

Avritzer, L. (2002) Democracy and Public Space in Latin America. Princeton: Princeton University Press.

Baiocchi, G. (2003) Participation, Activism, and Politics: the Porto Alegre Experiment. In A. Fung \& E.O. Wright, eds. Deepening Democracy, Institutional Innovations in Empowered Participatory Governance. London and New York: Verso.

Bank, W. (1997) World Development Report 1997: The State in a Changing World. Oxford: Oxford University Press.

Bank, W. (2000) Working Together: The World Bank's Partnership with Civil Society. Washington, DC: World Bank.

Benhabib, S., ed. (1996) Democracy and Difference: Contesting Boundaries of the Political. New Jersey: Princeton University Press.

Budiman, A. \& Törnquist, O. (2001) Aktor Demokrasi: Catatan tentang Gerakan Perlawanan di Indonesia. Jakarta.

Cheema, S. \& Rondinelli, D., eds. (2007) Decentralising Governance: Emerging Concepts and Practices. Washington: Brooking Institution Press.

Crib, R. (1990) The Indonesian Killings 1965-1966: Studies from Java and Bali. Monash: Centre of Southeast Asian Studies.

Dwipayana, A.A. (2004) Bangsawan dan Kuasa: Kembalinya Para Ningrat di Dua Kota. Yogyakarta: IRE Press.

Dyrberg, T. (1997) The Circular Structure of Power: Politics, Identity, Community. London: Verso.

Erb, M. \& Sulistiyanto, P. (2009) Deepening Democracy in Indonesia? Direct Elections for Local Leaders (Pilkada). Singapore: ISEAS Publishing.

Fauzi, N. (1999) Petani \& Penguasa: Dinamika Perjalanan Politik Agraria Indonesia. Yogyakarta: Pustaka Pelajar.

Ferguson, J. (1994) The Anti-politics Machine: Development, Depoliticisation and Bureaucratic Power in Lesotho. Minneapolis: University of Minnesota Press.

Fine, B. (2001) Social Capital and Social Theory. London: 
Routledge.

Fine, B., Lapavitsas, C. \& Pincus, J., eds. (2003) Development Policy in the Twenty-fisrts Century: Beyond the Washington Consensus. London: Routledge.

Hadiz, V.R. (2010) Localising Power in Post-Authoritarian Indonesia: A Souteast Asian Perspective. Stanford: Stanford University Press. Handayani, S. (2006) Merajut Harapan Menuju Perubahan. Solo: KOMPIP Solo and The Ford Foundation.

Handayani, S. (2006) Pelibatan Masyarakat Marginal dalam Perencanaan dan Penganggaran Partisipatif (SebuahPengalaman di Kota Solo). Solo: KOMPIP.

Harris, J. (2002) Depolitising Development: The World Bank and Social Capital. London: Routledge.

Harris, J., Stokke, K. \& Törnquist, O. (2004) Politicising Democracy: The New Local Politics of Democratization. London: Palgrave.

Histiralludin, M. (2004) Bergumul Bersama Masyarakat: Berbagi Cerita Proses Perencanaan Partisipatif di Kota Solo. Solo: IPGI Solo.

Isaac, T.M.T. \& Franke, R.W. (2002) Local Democracy and Development; The Kerala Peoples's Campaign for Decentralized Planning. Boston: Rowman\& Littlefield Publishers, Inc.

Laclau, E. (2005) On Populist Reason. London: Verso.

Laclau, E. \& Mouffe, C. (1985) Hegemony and Socialist Strategy: Towards a Radical Democratic Politics. London: Verso.

Larson, G.D. (1990) Masa Menjelang Revolusi: Keraton dan Kehidupan Politik di Surakarta 1912-1942. Yogyakarta: UGM Press.

Lay, C. (2000) Eksekutif and Legislatif Daerah: Penelitian tentang Potensi Konflik antara DPRD and Birokrasi di Daerah. Research Report. Jakarta: Kemenristek \& LIPI.

Lay, C. (2010) Broken Linkages: A Preliminary Study on ParliamentCSOs Linkages in Indonesia. In Panel on "Indonesian Democracy in Comparative Perspective" at Euroseas. Guttenberg, 26-28 August.

Manor, J. (2010) Beyond Clientelism: Digvijay Singh's Participatory Pro-Poor Strategy in Madhya Pradesh. In Price, P. \& EngelsenRuud, A. Power and Influence in India: Bosses, Lords and Captains. 
London, New York and New Delhi: Routledge.

Nordholt, H.S. (2004) Decentralization in Indonesia: Less State: More Democracy? In Harriss, J., Stokke, K. \& Törnquist, O. Politicising Democracy. The New Local Politics of Democracy. New York: Palgrave Macmillan.

Nordholt, H.S. \& van Klinken, G., eds. (2007) Renegotiating Boundaries: Local Politics in Post-Suharto Indonesia. Leiden: KITLV Press.

Pemberton, J. (2003) “Jawa": On the Subject of "Java". Jakarta: Mata Bangsa.

Pratikno (2005) Initiating Citizen Participation in Local Policy Making in Indonesia:The Case of Surakarta Municipality in the Post Authoritarian Regime, 1999-2002. In Conference on Participatory Planning and Budgeting in America and Asia, Tokyo and Kobe.

Priyono, A., Samadhi, W.P. \& Törnquist, O. (2007) Making Democracy Meaningful: Problems and Options in Indonesia. Jakarta: Demos.

Putnam, R. (1993) Making Democracy Work: Civic Traditions in Modern Italy. New Jersey: Princeton University Press.

Rifai, A., Gunawan, P., Bachry, S. \& Kartika G., V. (2009) Geliat Partisipasi Kelompok Sektoral: Studi Kasus Kota Surakarta. In Suhirman, ed. Partisipasi, Reformasi Kelembagaan, dan Alokasi Penganggaran: Pelajaran dari Lima Daerah. Bandung: FPPM and Yayasan Tifa.

Robison, R. \& Hadiz, V.R. (2004) Reorganising Power in Indonesia: The Politics of Oligarchy in an Age of Markets. London: Routledge Curzon.

Samadhi, W.P. \& Warouw, N., eds. (2009) Building Democracy On The Sand: Advances and Setbacks in Indonesia. Yogyakarta \& Jakarta: Demos-PCD Press.

Shiraishi, T. (1997) Zaman Bergerak: Radikalisme Rakyat di Jawa 1912-1926. Jakarta: Pustaka Utama Grafiti.

Sidel, J.T. (1999) Capital, Coercion, and Crime; Bossism in the Philippines. California: Stanford University Press.

Suhartono (1991) Apanage dan Bekel: Perubahan Sosial di Pedesaan 
Surakarta 1830-1920. Yogyakarta: Tiara Wacana.

Suhirman (2009) Partisipasi, Reformasi Kelembagaan and Alokasi Anggaran: Pembelajaran dari Lima Daerah. Bandung: FPPM \& Yayasan Tifa.

Tharakan, P.K.M. (2004) Historical Hurdles in the Course of the People's Planning Campaign in Kerala, India. In Harris, J., Stokke, K. \& Törnquist, O. Politicising Democracy. The New Local Politics of Democratisation. New York: Palgrave Macmillan. Törnquist, O. (2009) Power, Conflict and Democracy: The Analytical Framework. PCD Journal, Vol. 1 No. 1-2(Approaching Conflict and Democracy in South and Southeast Asia).

Törnquist, O., Webster, N. \& Stokke, K. (2010) Rethinking Popular Representation. London: Palgrave. 
From Populism to Democratic Polity ... 